\title{
Canada 150: exhibiting national memory at the Canadian Museum for Human Rights
} Angela Failler

\begin{abstract}
This paper features an analysis of the Canadian Museum for Human Rights (CMHR) and its showcase for 'Canada 150', the sesquicentennial anniversary of Canadian Confederation. Particular attention is paid to how the Museum frames national memory, and its responsiveness (or lack thereof) to critiques and re-framings of Canada 150 by Indigenous artists, activists, historians and community leaders. Since opening to the public in 2014, the CMHR has had a mixed reception, including criticism for inadequately addressing Canada's colonial past and present, privileging narratives of state benevolence and downplaying 'missteps' when it comes to Canada's own human rights and Indigenous rights record. Recognizing that national museums have long served the colonial project of state formation and official memory, this paper nonetheless tries to notice potential openings for decolonizing or unsettling Canada 150 at the CMHR. Shoal Lake 40 First Nation's Museum of Canadian Human Rights Violations is taken up as a counter example.

Keywords: Canadian Museum for Human Rights; politics of recognition; Shoal Lake 40 First Nation; Museum of Canadian Human Rights Violations; Indigenous rights; decolonizing museums
\end{abstract}

Submitted to Citizenship Studies, Volume 22, Issue 4, 2018 
Occasions like Canada's sesquicentennial anniversary are what art historian Ruth B. Phillips (2006) calls 'show times', that is, 'moments when museums organize comprehensive and definitive exhibitions in connection with a major event in the life of the community' (emphasis in original, 121). 'Canada 150' at the Canadian Museum for Human Rights (CMHR) is a case in point, providing a unique snapshot into how knowledge about human rights is produced through particular framings of citizenship, nationhood, history and memory. By way of examining the CMHR's Canada 150 exhibits and programming, alongside a broader consideration of its situatedness on Treaty One Territory in Winnipeg, Manitoba, this paper is concerned that the Museum largely missed a chance to lead critical conversations on the significance of the sesquicentennial moment. In particular, this moment would have been a prime time for the Museum to set an example for how it could participate in decolonization, especially as it comes on the heels of the Canadian Truth and Reconciliation Commission's call to public museums to act towards redressing the legacy of Indian Residential Schools and ongoing colonial violence (TRC 2015a, 2015b). But with the exception of one exhibit launched at the eleventh hour and two shyly publicized discussions on government apologies, the CMHR's sesquicentennial showcase replays a common-sense 'multicultural nationalism' (GordonWalker 2016) where Indigenous inclusion within the story of 'Canada's human rights journey' means being folded into a depoliticized framework of cultural diversity. Seemingly unresponsive to critiques and re-framings of Canada 150 by Indigenous artists, activists, historians and community leaders, much of the showcase persists in hegemonic forms of national memory and what Dene scholar Glen Coulthard (2014) calls a 'colonial politics of recognition'.

Concomitant with these limited framings, the Museum tends to assume and cultivate an affective orientation of 'cozy nationalism'. Cozy nationalism here works to promote a general sense or feeling of 'collective emotional union' (Beauchamps cited in Di Gregorio and Merolli 2016, 938) through the repeated use of tropes such as belonging, empathy, pride and hope. These tropes are taken for granted as universally shared values rather than reflections of the specific political and economic investments of the CMHR in a desire to reproduce comfortable or 'lovely' knowledge (Pitt and Britzman 2003). In turn, they undergird the Museum's Canada 150 showcase, prompting museumgoers to identify with particular ways of 'feeling Canadian' (Bociurkiw 2011) that reinforce the settler colonial status quo.

This paper then turns to Shoal Lake 40 First Nation's Museum of Canadian Human Rights Violations (MCHRV). The MCHRV is a counter-museum of sorts that launched at the same time as the CMHR, strategically piggybacking on the national attention generated by the latter's grand opening. Inviting visitors to witness the ongoing ravages of colonial expansion in their community, the MCHRV creates opportunities to engage what education theorists Alice Pitt and Deborah Britzman (2003) call 'difficult knowledge'. Distinct from comfortable or lovely knowledge, difficult knowledge is knowledge that upsets familiar and dominant frameworks for understanding the world and our places within it. By engaging difficult knowledge, the MCHRV brings into further relief the limits of the CMHR's diversity framework, cozy nationalism and reiterations of colonial memory. Moreover, it provides an example of curatorial practice that moves beyond an inclusion-recognition logic to one that prioritizes a redistribution of power and resources through the restitution of Indigenous rights to land and water. Indigenous peoples in and beyond Canada continue to suffer by dispossession of territory and resources, and thus insist on their repatriation as key to the process of decolonization (Coulthard 2014; Tuck and 
Yang 2012; Wolf 2006). The role that museums might play in this process remains an open question.

The year 2017 marked the sesquicentennial or 150th anniversary of Confederation popularly celebrated as 'Canada's birthday', including the 'historic struggles that helped achieve some of our fundamental freedoms and rights' (CMHR 2017a). The last century and a half, however, has not been cause for celebration for everyone. People continue to experience systemic oppression despite the enshrinement of certain equalities and protections in Canadian law and the Constitution, and many continue to suffer in the wake of state-perpetrated violences despite official apologies and other gestures of reconciliation and redress (Henderson and Wakeham 2013). Even mainstream national news media have given voice to the 'conflicted' opinion that celebrating Canada 150 may not be appropriate while, for instance, there are First Nations, Métis and Inuit communities living in 'third world conditions' and states of emergency. Indigenous historians, activists, artists and community leaders have, themselves, boycotted and/or reframed Canada 150 in various ways, including as a 'celebration' of colonialism (Sumanac-Johnson 2017), 150 years of alienation and betrayal (Ladner and Tait 2017) and the denial of '14,000 years of indigenous history on this continent' (Arnaquq-Baril qtd Kassam 2017). Others have taken the opportunity to celebrate Indigenous resilience and resurgence in the face of Canada's assault on Indigenous peoples (Belcourt 2017; Winnipeg Art Gallery 2017), and to organize national days of action (Idle No More 2017; Unsettling Canada 150 n.d.).

In the context of museums, Inuk scholar and curator Heather Igloliorte observes that First Peoples, and particularly artists, have been reluctant to participate in Canada 150 celebrations or to accept funding from commemorative programs. 'To do so', she explains, 'is to tacitly ask us to also celebrate, or at least ignore, our shared history of attempted genocide and ongoing colonialism', adding, 'I question how Canada can justify the heavy price tag for these nationwide activities while telling First Nations, Métis and Inuit peoples that it does not have the means to honour its responsibility to provide its citizens with urgent, basic needs' (Mctavish et al. 2017, 232). For its part, the CMHR forged ahead with Canada 150 celebrations, with two notable exceptions: Rights of Passage, an exhibit that opened on 10 December 2017, months after the rest of its Canada 150 showcase was staged, and After the Apology, a new dialogue series intended to explore the aftermath of government apologies for historic wrongs. As a curatorial effort that acknowledges, in one instance, how 'the Canadian state ... systematically introduced policies to sever Indigenous peoples' relationships with the land and environment and to destroy their identities and ways of life' (CMHR 20171), Rights of Passage constitutes an opening, and a potential unsettling of settler colonial framings of national memory. At the same time, however, its conspicuous belatedness reveals the state-sponsored Museum's struggle to be 'part of the conversation' on reconciliation with Indigenous peoples (CMHR 2017e) and responds to pressing issues in a timely way. ${ }^{1}$ After the Apology, which the Museum calls a Canada 150 'signature project' despite the minor publicity it has been afforded, has consisted of two events thus far, one on Canada's apology for residential schools and the other on its apology for the internment of Japanese Canadians during WWII. This programming initiative might have also been a potential opening into critical engagement with the sesquicentennial anniversary, but was overshadowed by the Museum's emphasis on its other, more celebratory offerings. ${ }^{2}$

\section{Situating the Canadian Museum for Human Rights}


The CMHR is the first national museum in Canada to be built outside of the National Capital Region. Its \$350-million-dollar design boasts 47,000 square feet of gallery space within a 260,000 square foot multi-level structure composed of materials from around the world for which it has won several architectural awards. The CMHR is located in Winnipeg, Manitoba, a mid-sized prairie city often noted for having the largest urban Indigenous population in Canada a population that, on the one hand, is among the most disenfranchised and stigmatized of the broader community and, on the other, has made Winnipeg a thriving centre for Indigenous art, political activism and cultural revivification. Winnipeg is located on the traditional territory of the Anishinaabeg, Cree, Oji-Cree, Dakota and Dene peoples, and is the homeland of the Métis Nation. The Museum itself sits on a parcel of land in an area referred to as 'The Forks' at the intersection of the Red and Assiniboine rivers. Noted as an 'early Aboriginal settlement', today the area is one of the city's most active tourist and commercial zones (The Forks n.d.). ${ }^{3}$

The formal mandate of the CMHR, as expressed in its mission statement is: (1) to preserve and promote Canadian heritage at home and abroad; (2) to contribute to Canadian collective memory and sense of identity of all Canadians; and (3) to inspire research, learning and entertainment that belong to all Canadians (CMHR 2017b). As set out in the Canadian Museums Act Section 15.2, the purpose of the CMHR is 'to explore the subject of human rights, with special but not exclusive reference to Canada, in order to enhance the public's understanding of human rights, to promote respect for others and to encourage reflection and dialogue'. The Museum's name, the Canadian Museum for Human Rights (rather than 'of Human Rights'), intends to signal its commitment not only to record and display but also to promote and expand human rights (CMHR 2011). The Museum also emphasizes its approach as being that of an 'ideas museum', showcasing concepts rather than things (CMHR 2014-15). True to form, the majority of its collection consists not of objects or artefacts but of narratives and images presented by way of digital panels and interactive screens distributed across thirteen themed galleries.

In a speech delivered in 2012 to l'Union nationale métisse Saint-Joseph du Manitoba (the longest-standing Métis organization in Canada), then-CMHR President and CEO Stuart Murray elaborated further on the Museum's approach as one that relies on the power of stories, including those featuring 'Indigenous content':

I think our visitors will find particular power in these stories for two reasons. The first, and most important, is that there is an authenticity to the stories we share at the Canadian Museum for Human Rights, and it's an authenticity that comes from avoiding the paternalistic, colonial approach to Indigenous content that museums historically have at times been guilty of. First Nations and Métis content at the Canadian Museum for Human Rights has been directly shaped by First Nations and Métis people. At every stage. For many reasons, this is far better than simply appropriating content, but it will ultimately mean a distinctive authenticity, richness and power to the stories our visitors encounter. Moreover, we want to see this approach ultimately lead to a decolonization of the way western museums explore Aboriginal culture. (CMHR 2012) Murray's statement is striking for the confidence with which he sets the CMHR apart from the history of colonial museum practice, explicitly naming 'decolonization' as an objective of the Museum. However, since his speech and the CMHR's public opening in Fall 2014, the Museum has been critiqued for inadequately addressing Canada's colonial past and present, privileging narratives of state benevolence and downplaying 'missteps' when it comes to Canada's own 
human rights and Indigenous rights record (see Busby, Muller, and Woolford 2015; Clearsky 2013; Dhamoon 2016; Failler, Ives, and Milne 2015; Hankivsky and Dhamoon 2013; Lehrer 2015; Logan 2014; Moses 2012; Scott 2015; Wong 2014). Recognizing that national museums have long served the colonial project of state formation and official memory (Lonetree 2012), this paper nonetheless tries to notice potential openings for 'unsettling Canada 150 ' at the CMHR, and signs of whether/how decolonization remains a commitment.

\section{Launching Canada 150 at the CMHR: colonial frames of remembrance and recognition}

Programming for Canada 150 at the CMHR began in 2016 with a special event called Countdown to Canada's 150th! offering free admission, performances and 'chats' with interpreters showcasing some of the Museum's stories on themes of youth, diversity and inclusion, the environment and reconciliation (CMHR 2017f). Advertised through the Museum's website and social media platforms, prospective visitors were encouraged to 'Bring the whole family for one last day of summer fun!' (2017f). Reminiscent in tone to a promotional pitch released in the months leading up to the Museum's inauguration ('For the cost of a night at the movies or pizza for the family, visitors can experience a journey of inspiration unlike anything they've seen before, inside one of the most stunning buildings in Canada', [CMHR 2014]), Countdown to Canada's 150th! promises a budget friendly, family friendly celebration, anticipating the spirit of the showcase to come.

1867: Rebellion \& Confederation was the first exhibit the CMHR presented as part of its Canada 150 showcase. Originally developed by the Canadian Museum of History (CMH) in Gatineau, Quebec, 1867 is curated around a collection of 124 artefacts to 'explor[e] the struggle for liberty, democracy and rights that led to the proclamation of Confederation on July 1, 1867'

(CMHR 2017k). Among the exhibit's artefacts are, to name but a few, weapons used during the rebellions of 1837-1838; a pair of eyeglasses found in the ash from the 1849 burning of Parliament; cobblestones thrown at Lord and Lady Elgin; the diary of Mercy Coles, who accompanied her father to the conferences that led to Confederation; and the pocket watch of Sir John. A. Macdonald, Canada's first Prime Minister (CMHR 2016b). Each artefact is described in a way that contributes to an overarching narrative of Confederation and its rebellions as constituting the 'roots of democracy' in Canada (CMHR 2017a).

The CMHR extended 1867 through programming including two on-site activities. The first, 'What's Your Take?' asked museumgoers, 'What do you think were the important news topics for Canadians at the time of Confederation? Choose headlines to make up your own fictional historical newspaper! Then, have your picture taken with your front page headline and share with family and friends'. The second, 'Discovery Adventure', invited museumgoers to 'Visit the Canada of 1867 in this engaging scavenger hunt activity! Explore the human rights experiences of diverse groups in Canada in the years before Confederation. Discover the multiple perspectives that have shaped our shared journey towards the creation of a Canadian identity' (CMHR 2017j). The Museum Boutique (i.e. gift shop) announced its own promotion: 'Bring a piece of 1867 home with you!' Available for purchase were calligraphy pens and inks ('discover the classic art of calligraphy and revive the lost art form of handwritten notes'), leather-bound journals and paper and reproductions of maps from 'circa 1867' (CMHR 2017c). 
The CMHR also published a three-part blog series on 1867 , penned by an in-house communications advisor and former curator-researcher. The series elaborates on the exhibit's collection of artefacts and the CMHR's adaptations of the CMH's original. Adaptations by host museums of exhibits travelling from other sites are commonly undertaken for both pragmatic and conceptual/ideological reasons (for example to accommodate available physical space to better 'fit' with the thematics and/or political investments of the host museum). In this case, what the CMHR describes as being unique to its adaptation of 1867 is recognition of 'the impact that immigration, expanding settlement, and colonial politics had on existing Indigenous nations', noting that 'In 1867 many people were left out of the debates about Confederation, including Indigenous peoples, women and others' (CMHR 2017a). This recognition, or the Museum's attempt at it, is exemplified in one of the blog posts from the series. The post, titled 'Seven Fascinating Artifacts You Can See at the 1867: Rebellion \& Confederation Exhibition', is worth quoting at length for its discussion around a 'Métis Saddle' dated from 1846:

Responsible government did not include everyone. Women, Indigenous peoples and many others were excluded from these new democratic rights. For Indigenous people in particular, who already inhabited the land, growing European settlement was placing increasing pressure on their societies. Indigenous people responded by mobilizing to protect their rights. They physically protested incursions on their land and wrote letters to the Imperial government in London. At the Red River Colony in what was then called the Northwest Territories, First Nations, French, English and Métis all worked to resolve growing tensions over land and resources. This beautiful Métis saddle, decorated with dyed porcupine quills, speaks to the vibrancy of Indigenous cultures in British North America, in the face of opposition and oppression from settler governments. (CMHR 2016b)

At first glance, this passage's crediting of Indigenous peoples as the first inhabitants of the land and their resistance to colonial 'incursions' seems an important corrective to the lack of attention to such matters in the original exhibit. Judging by the CMH's curatorial statement and online reference materials, the original proffers a conventionally historiographic storytelling (read: patriarchal narrative of colonial progress) of 'the birth of today's Canada' via the founding of Canada's English/French biculturalism credited to the 'Fathers of Confederation' (CMH 2016) a narrative that professor of Aboriginal Law James (Sa'ke'j) Youngblood Henderson calls a 'colonial myth' for its denial of Canada's relational beginnings with Indigenous peoples and nations (Henderson 2017, 277). The CMHR's adaptation, then, seeks to remedy the exclusion of 'Indigenous people, women and others' by acknowledging their existence and adding them to the story of Confederation. Inclusion of the Métis saddle, for instance, serves as an indexical sign, a reminder of the Métis having been there.

A closer read of this passage, however, reveals its limits in terms of re-remembering the history of Confederation beyond a colonial framing. The sovereignty of the new system of 'responsible government' imposed on the peoples of the land in and of itself goes unquestioned here, taken for granted as both inevitable and good. What is constructed as the problem is that some people were initially 'left out' of this (otherwise inevitable and good) system that afforded democratic rights only to those it deemed legitimate citizens. The practices and policies carried out in order to establish the new federal Dominion of Canada, including the redrawing of boundaries around provinces and territories and encroachments upon pre-existing treaty relationships with Indigenous nations, are euphemized as 'pressure' resulting from 'growing European settlement', 
ultimately relieved through the ushering in of Confederation. Confederation, in other words, is presented as the logical outcome of a collective struggle that the First Nations, French, English and Métis 'all worked to resolve', rather than the (re)assertion of dominance by colonial forces that paved the way for subsequent forms of legislation designed to further subjugate Indigenous peoples including successive, paternalistic Indian Acts (Henderson 2017). The neutralizing language used in this passage downplays the injustice of colonial dispossession, reducing its effects for Indigenous peoples, women and others to being 'excluded from voting' (CMHR 2017k).

In this context, the description of the Métis saddle as a 'fascinating' artefact that survived in the face of 'opposition and oppression from settler governments' performs a sigh of relief: Indigenous cultures have persisted in spite of colonial intrusions. Museumgoers can marvel at Indigenous resilience and the beauty of traditional Métis quillwork. They can feel proud and rest assured by this nostalgic, celebratory version of Confederation (if it was ever threatened by the prospect of exclusivity). The CMHR's attempted recognition here manages to side-step what clearly constitutes difficult or uncomfortable knowledge for the Museum and its perceived publics: that 'Canadian democracy' required and was founded upon the deliberate and violent dispossession of Indigenous peoples from territory and resources. Indigenous peoples (and women and certain others) were not simply 'forgotten' or 'left out' of this new society as if their exclusion was an oversight or unintended consequence of colonial governance. Colonial governance necessitated their exclusion, through which patriarchal, imperialist powers united and asserted their sovereignty under the name of 'Canada'.

That the CMHR's version of 1867 fails to unsettle colonial memory or disrupt the celebratory narrative of Canada 150, instead rehearsing a story of national progress and a defense of the expropriation of land and resources for the purposes of nation building is, perhaps, not altogether unexpected. In addition to its $\mathrm{CMH}$ developers, the sponsors for this exhibit include the Government of Canada (GOC) and the Canadian Association of Petroleum Producers ('the voice of Canada's upstream oil, oil sands and natural gas industry' [2017]). But that the CMHR chose 1867 as its inaugural exhibit for Canada 150 is meaningful. In comparison to its other exhibits for this occasion, 1867 is the most conventional in its historiographic, artefact-based approach to marking 'Canada's birthday', and in its adherence to official (colonial) memory of Confederation. As a centrepiece of the Museum's Canada 150 showcase, it thus underscores not only the Museum's reliance on government and corporate sponsorship, but its tendency to maintain the status quo whereby the strategy for recognizing those who have been 'left out' of human rights is to recover or include them within the terms of citizenship conferred by the settler-state, without questioning the authority of those terms.

Contrary to a decolonizing approach, this strategy illustrates what Dene scholar Glen Coulthard calls a 'colonial politics of recognition'. In Red Skin White Masks(2014), Coulthard critiques the "now expansive range of recognition-based models of liberal pluralism that seek to "reconcile" Indigenous assertions of nationhood within settler state sovereignty' (3). He traces a shift from when colonial power was structured through the enforcement of explicit tactics of genocide and assimilation, to when Indigenous anti-colonial activism during the 1960s and 1970s forced this power to modify itself into a 'seemingly more conciliatory set of discourses and institutional practices that emphasize recognition and accommodation' (6). Building on other political theorists and Indigenous thinkers such as Taiaike Alfred and Leanne Simpson, Coulthard argues 
that despite this modification or shift, colonial dominance has remained firmly entrenched in the relationship between Indigenous peoples and the state wherein 'recognition' and

'accommodation' are only conferred in ways that do not fundamentally threaten the sovereignty of the settler-state or continued access to Indigenous lands and resources (156). In other words, these newer terms of recognition are still set by the colonial state in the interests of the colonial state and its institutions (17). This is reflected, for example, in the ways that the CMHR in its Canada 150 showcase tends to recognize Indigenous peoples and traditions; that is, by including or accommodating them within a diversity/liberal pluralist model that celebrates Indigeneity as further evidence of Canada's rich 'multicultural' history but does not acknowledge the fundamental problem of the settler state's power of entitlement and authority to bestow this recognition/accommodation in the first place.

\section{Canada Day at the CMHR: showcasing multicultural nationalism}

After a five-month run of 1867, the CMHR focused its 150 showcase around Canada Day, observed on 1 July 2017. The wider Forks area where the Museum is situated was one of two locations in Winnipeg that Canada Day events and activities were concentrated. As such, the Museum became a literal frame or backdrop for much of the City's 150 celebrations, its enormous edifice inescapable from this particular vantage point (Figure 1). Throughout the week, the CMHR illuminated its Tower of Hope - a 23-story glass architectural feature that sits atop the building - in 'maple-leaf red' (CMHR 2017g). The Museum's Bistro advertised 'A food journey across Canada' featuring 'The Great Canadian Menu'. The Museum Boutique announced, 'Show your Canadian pride in style!' with an array of Canada 150 themed merchandise (2017g). On Canada Day itself, the Museum offered a \$5 admission to visitors willing to show their 'Canadian pride' by wearing red and white, singing the national anthem, or finding a 'unique way to say "Happy Birthday" to Canada' (CMHR 2017d).

Figure 1. View from the Forks on Canada Day, 1 July 2017 (photo credit: author). 


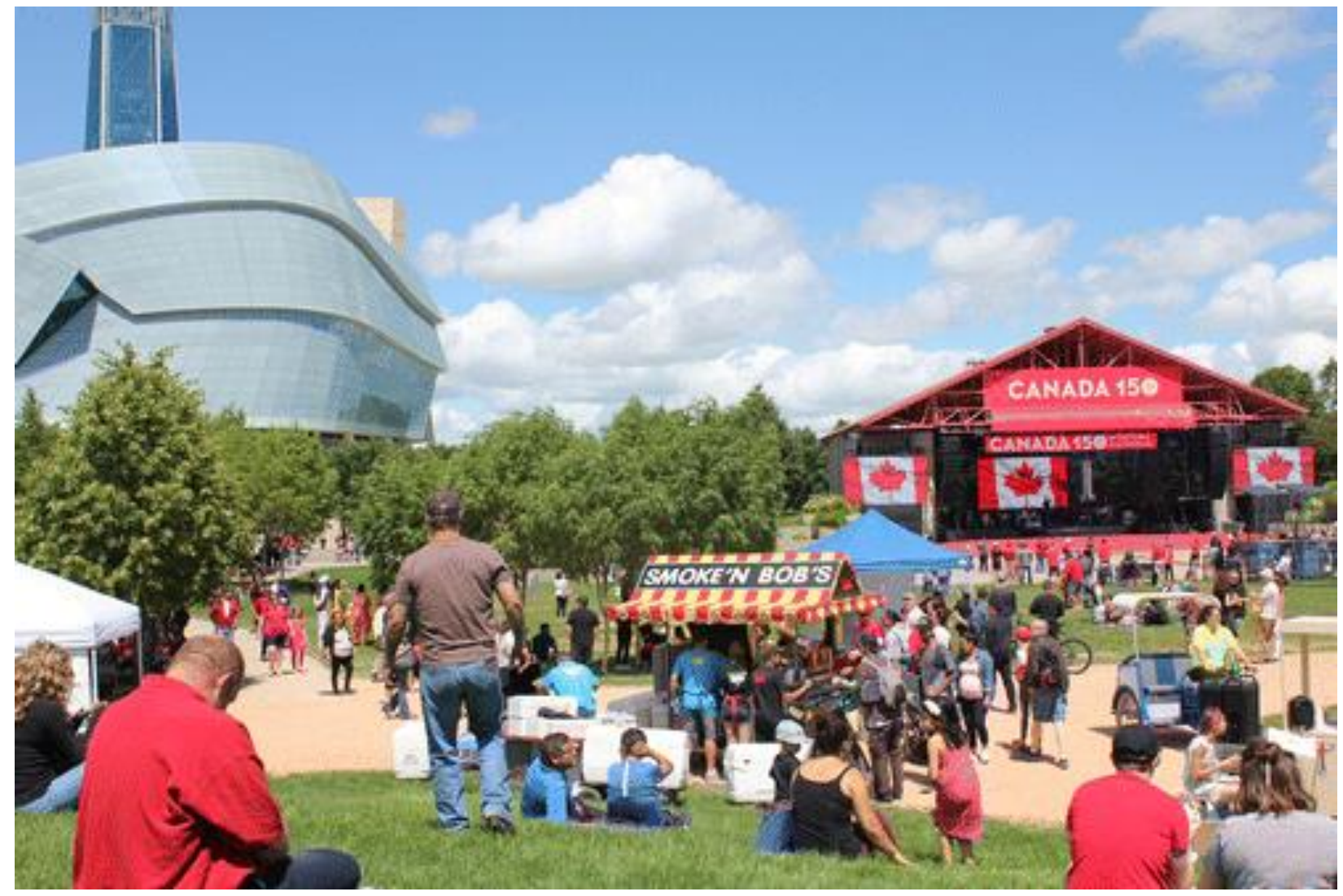

I spent Canada Day at the CMHR paying particular attention to its dedicated 150 itinerary, which included two 'Family Programming' activities and three featured exhibits. Immediately proximate to the entrance and ticketing area on the lower level, visitors are normally greeted by a giant projection wall animated by silhouette figures handwriting the word 'welcome' in multiple languages. On Canada Day, the wall was transformed into We Are Canada, an 'interactive photo and video mosaic of Canada'. Museumgoers were invited to 'Add your face to the Canadian landscape' by taking a 'selfie' at a nearby photo/video booth that uploads images to the projection. The end result was a giant flag-like banner emblazoned with the Government of Canada's official Canada 150 logo surrounded by different faces, including some groupings of people within a single frame (Figure 2). On the surface, this 'interactive' exhibit appears to be a nod to the new museology tenet of participatory museumgoing where visitors are encouraged to become more than just 'passive spectators' by getting involved in the creation of museum content and meaning-making themselves, intended to break down the conventional hierarchy between presumed-to-know museum experts and presumed-ignorant museum visitors (Ross 2004; Stam 1993; Vergo 1989). But what is to be made of this version of participation? Where the new museologists saw participatory museumgoing as a challenge to the authoritative structure and voice of the museum, here participants are incorporated into the exhibit in a way that basically implicates them in a massive branding of Canada 150.

Figure 2. Detail from We Are Canada (photo credit: author). 


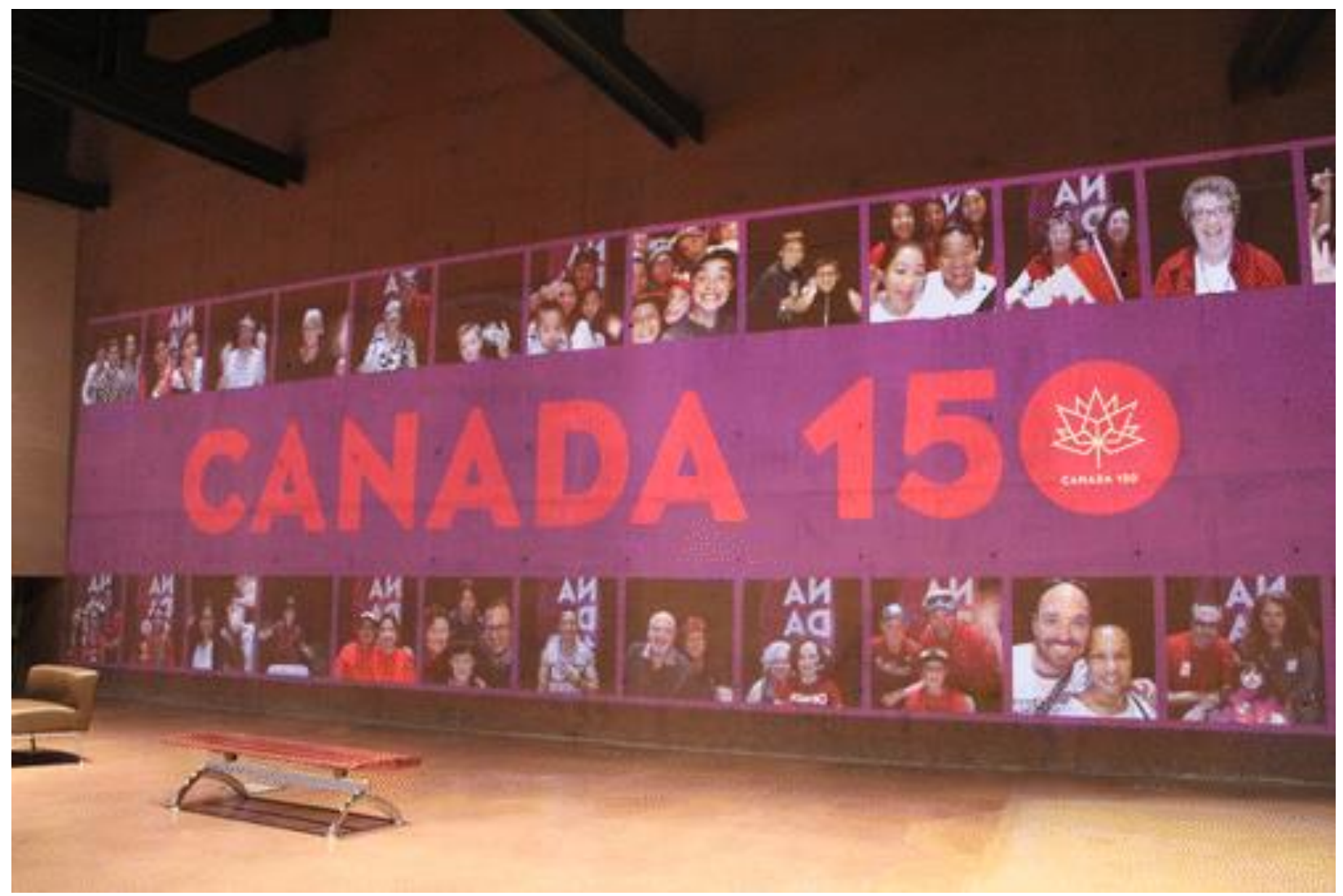

We Are Canada can be read as an expression of what Caitlin Gordon-Walker (2016) in her book on Canadian museums calls 'multicultural nationalism', an ideological framework wherein the nation-state is imagined as an idealized community and diversity is celebrated along with a sense of equal belonging among all of the state's citizens (7). Multicultural nationalism in We Are Canadais reiterated by the effect of its smiling faces being knit together as if one, big, happy family quilt, each frame unique but ultimately contributing to the same Canadian cloth. The exhibit announces, 'Canada has found unity in its diversity' and that this is 'a cause for celebration and hope' (11). Drawing on critical race theorists including Himani Bannerji, Sunera Thobani and Yasmeen Abu-Laban, Gordon-Walker goes on to explain that celebrating diversity has certain limits within this framework whose underlying principle demands that any recognition of difference 'must not challenge the unity, authority, or legitimacy of the nation, or the national state' (8). That diversity or difference must ultimately contribute to unity in accordance with a preconceived set of cultural values/ideologies about citizenship and the nation is reflected in the Museum's 150 showcase by the title of exhibits - e.g. We are Canadaalongside other instances where difference or diversity collapses into a singular notion of Canadianness (e.g. from the 1867 description: 'Discover the multiple perspectives that have shaped our shared journey towards the creation of $a$ Canadian identity', [emphasis added, CMHR 2017j]). Gordon-Walker argues further that public cultural institutions like museums convey ideals of multicultural nationalism in ways that 'revel in the perception that ... diversity is a product of Canada's historical and contemporary benevolence and inclusiveness' (23). This latter point, in particular, resonates with Coulthard's critique of a colonial politics of recognition, cautioning of approaches to 'reconciliation' that allow the state to perform self-congratulations for (conditionally) including Indigeneity within the narrative of its national past without having 
to substantively redistribute power and resources to Indigenous peoples and communities in the present - a critique that finds a specific response in Shoal Lake 40 First Nation's MCHRV (discussed further below).

Ascending next to the Museum's main level, I entered the Indigenous Perspectives Gallery where two museum educators were facilitating a Haudenosaunee Hand-Eye Coordination Game. Here visitors were given instructions for how to first build the game, which involved using scissors to cut out a circle of construction paper, punching holes into it, attaching a string with beads to one end, and a fixing small stick to the other (Figure 3). The aim of the game was to then fling the paper circle into the air and successfully catch/stab it with the small stick through one of the punched holes. The game, we were told, was traditional to the Haudenosaunee. ${ }^{4}$ With no further instruction or context, I asked one of the facilitators about the connection between the game and Canada 150. She validated my curiosity exclaiming 'good question!' and explained that while people were building or playing the game, she and the other educator would try to tell them about the origin of the name 'Canada', which comes from the Haudenosaunee 'Kanata' meaning 'village' or 'settlement'. This was intended as a way of bringing Indigenous knowledge into the story of Confederation - something I thought had potential as an opening into a critical conversation, but that without much uptake from visitors (from what I could see) rendered the game a rather tokenistic incorporation of Indigenous 'tradition' that situated the Haudenosaunee in a romanticized past, echoing colonial museum practices of depicting Indigenous peoples as a disappeared race and/or as pre-modern relics with quaint pastimes (Phillips 2011; West 2001).

Figure 3. Detail from Haudenosaunne Hand Eye Coordination Game (photo credit: author).

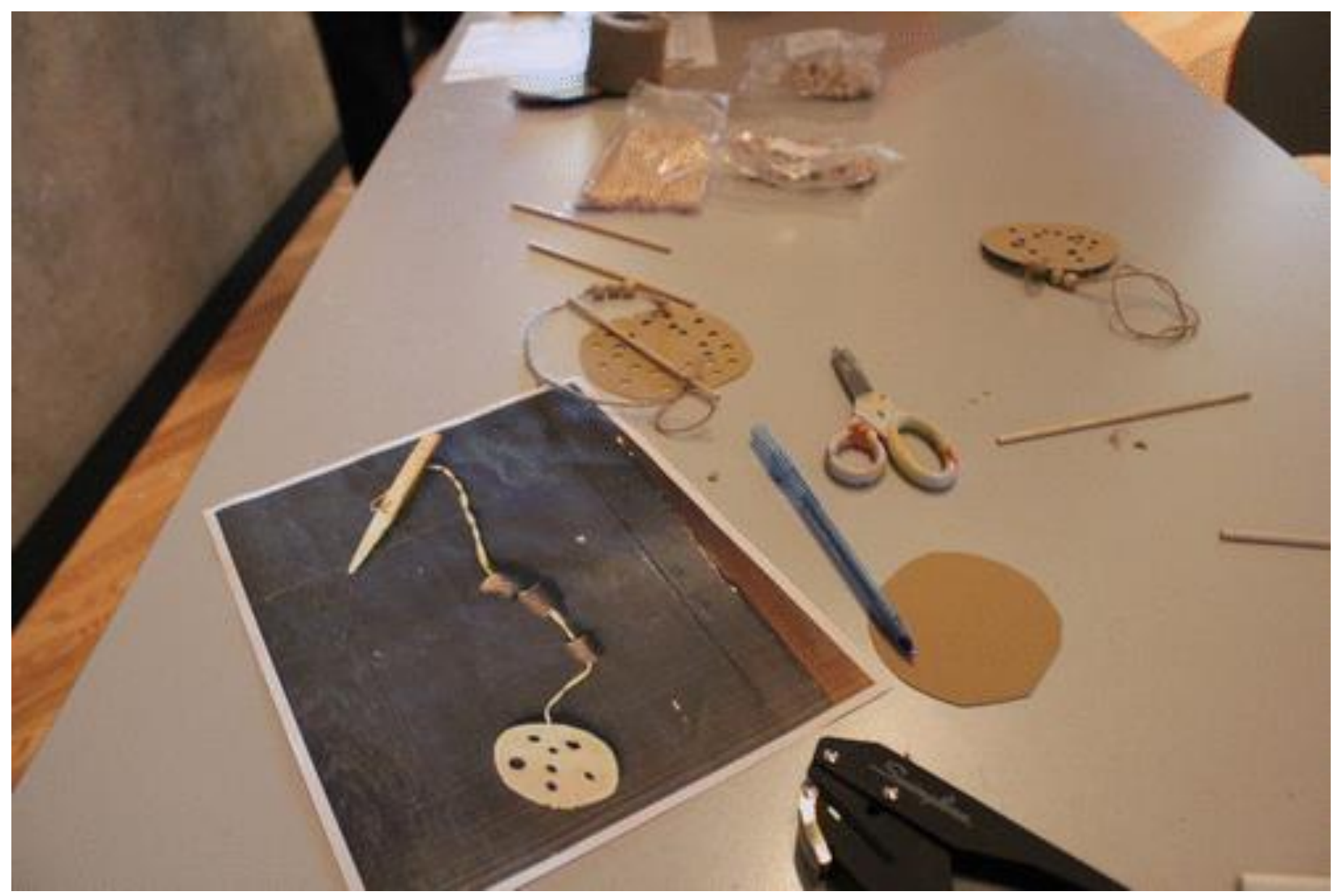


The second special programming activity for Canada Day, Canadians in Conversation, was located in the walkway between the Indigenous Perspectives gallery and the Canadian Journeys gallery. Museumgoers were asked here to 'Share one thing you would say to these people who have influenced human rights in Canada' including Nellie McClung, Viola Desmond, Louis Riel, Rosemary Brown, Elijah Harper, Pardeep Singh Nagra and Pierre Elliot Trudeau. Blank manila inventory tags and black markers waited on a table next to another museum attendant who explained the purpose of the exhibit ('to contribute to the dialogue on human rights'), and offered to hang visitors' completed tags from the walkway railing (Figure 4). One-paragraph biographies of the featured influential people were presented in English and French on placards that stood in the walkway (with the exception of Harper and Nagra's, for some reason, which made them appear as afterthoughts). Of the tags that participants wrote, most said things like 'Happy Canada Day', and 'Louis Riel, Bravo!' although a few stood out as a bit more substantive including 'Dear Viola Desmond, Thank-you for refusing to obey'. This activity, also clearly designed in the spirit of participatory museumgoing, nonetheless fell a bit flat as a 'dialogue' since none of the intended recipients of the notes were present, let alone living (with the exception, again, of Nagra who is the current Executive Director of the Sikh Heritage Museum of Canada and a former boxing champion that the CMHR had recently invited to speak on a panel discussion regarding sports and human rights during Asian Heritage Month; [CMHR 2016a]). Overall, Canadians in Conversation seemed to foster little in the way of dialogue, let alone critical dialogue on human rights; instead, these (hypothetical) conversations traded on tropes of belonging, pride and diversity to elicit sound-bytes of perfunctory gratitude to the 'influential figures' whose contributions were assumed either to be already familiar to museumgoers or to have been gleaned from what little information was provided by the (incomplete) set of placards.

Figure 4. Detail from Canadians in Conversation (photo credit: author). 


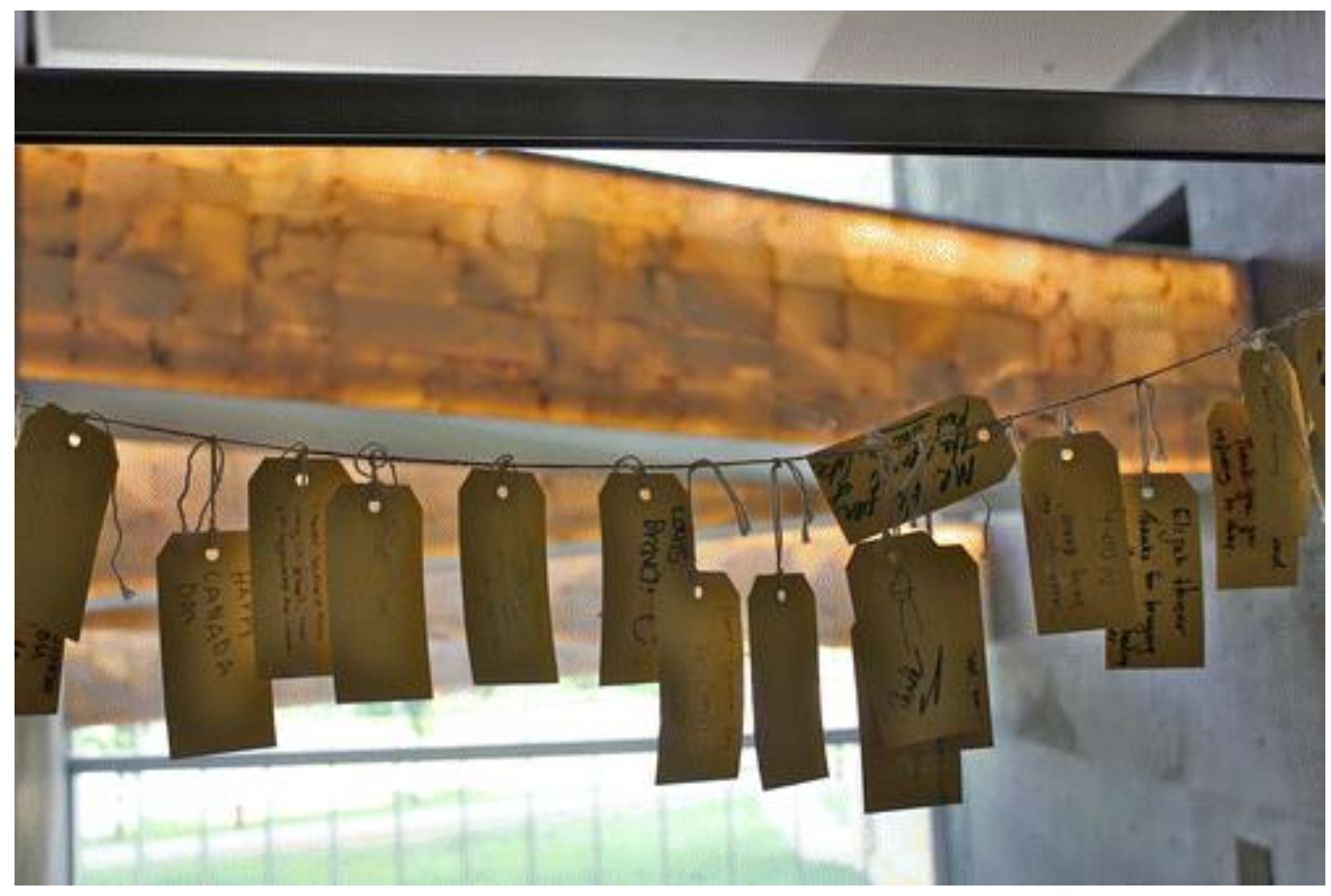

The CMHR developed Our Canada, My Story as a featured exhibit for its Canada 150 showcase with sponsorship provided by the GOC's Canada 150 Fund and additional support from Richardson Foundation \& Family (CMHR 2017h), the philanthropic arm of Canada's largest corporation of agriculture and food processing. Our Canada, My Story features seven portraits of people living in different regions of Canada. Upon entering the Expressions Gallery, visitors are met with the exhibit's curatorial statement:

How do human rights impact our everyday lives? Our Canada, My Story welcomes you to make a connection with different people across the country. Meet Ali, Widia, Kevin, Sylvia, Thomas, Shawn and Mona as they share their experiences with human rights. These stories explore what it means to work towards equality, inclusion and dignity for all Canadians. Their personal stories may remind you of your own experiences and challenges, or those of someone you know.

Consider how we are different, how we are the same - and what connects us all.

The portraits themselves are presented through short documentary films played on flat video screens, each set up in their own cul-de-sac with comfortable seating, an area rug, decorative lighting and a floor-to-ceiling banner with a written synopsis of the portrait alongside a largerthan-life close-up of the smiling face of its subject introduced only by their first name (e.g. 'Meet/Voici Widia') (Figure 5). The films run as 4-5 min vignettes across themes identified by the Museum as Indigenous rights and reconciliation, rights to health and food security, rights of refugees and resettlement, the rights of persons with disabilities, the rights of people of diverse sexual orientations and gender identities, freedom of expression and the impacts of historical human rights violations (2017h). The portraits include, for example, that of Mona Greenbaum, a Montreal-based activist and Executive Director of the LGBT Family Coalition, who struggles for 
and wins access to the same rights as heterosexual families for her lesbian partner, herself and their children under Quebec and Canadian law; and Sylvia Cloutier, a single parent living in Iqaluit, Nunavut who combats the crisis of food affordability/accessibility in the North by participating in community food sharing networks and learning about traditional food gathering and preparation.

Figure 5. Detail from Our Canada, My Story (photo credit: author).

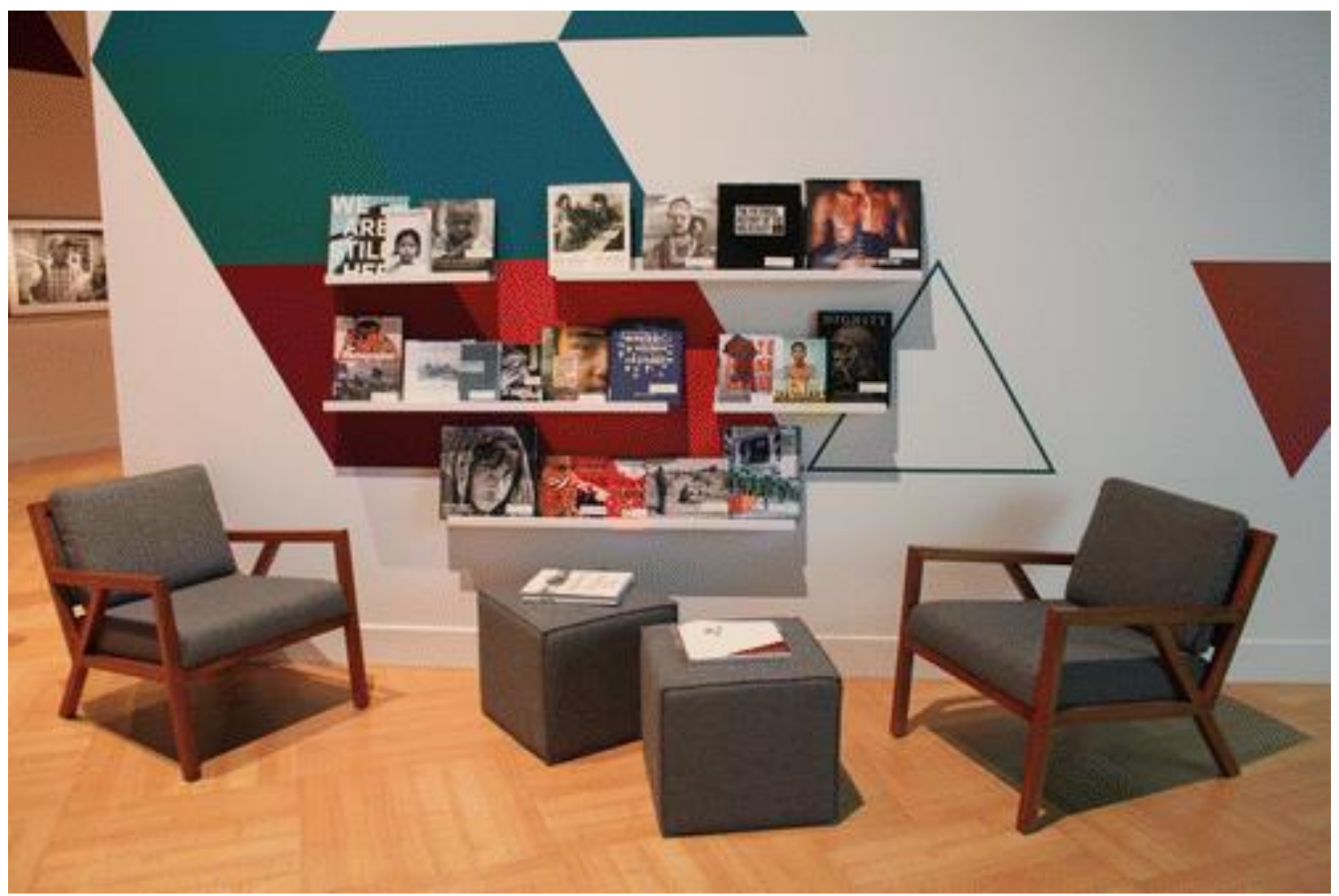

Of the CMHR's Canada 150 offerings to this point, Our Canada, My Story is perhaps the most thoughtful with respect to the context it provides for making connections between the past and present. The portraits featured here reference archival materials as well as personal and familial memories as they relate to contemporary issues. Notably, the portraits are also all presented as celebration-worthy success stories, emphasizing the individual agency of their subjects as supported by their local communities and, in some cases, the state's accession to their rights. Once discrimination faced by these subjects and/or their families is established, a resolution is found (if only in successive generations) leaving injustice to the past, safely sealed off from the present. For example, of the internment of his Japanese Canadian grandparents in Port Hardy, British Columbia during WWII, Kevin Takehide Lee admits, 'It devastates me that a country I'm so proud of turned their [sic] backs on them'. Kevin, however, starts a 'newcomers choir' that he describes as 'act[ing] as a bridge over cultural divides, generational divides [...], a powerful force that brings people together', allowing him to regain a sense of pride for himself and his community. Another portrait features Ali Duale, a Muslim-identified Somali refugee who after being in refugee camp in Kenya for seven years settles in Halifax with his wife and children and 
becomes a firefighter. Ali's vignette concludes with a quote of him saying, 'I'm very proud of being a Muslim and being Canadian. This is the beauty of this country. This is one of the icons of this land. We're a very multicultural, very diverse community and being Canadian is being who you are. There's no contradiction [...].'

Indeed, a sense of 'no contradiction' permeates the set of narratives chosen for Our Canada, My Story, including Ali's which fits seamlessly with the 'migration to liberation nation' narrative that David Murray (2014) observes is characteristic of hegemonic accounts of migration and asylum seeking wherein claimants are consistently represented as expressing desire and gratitude for the 'gift' of Canadian citizenship (465). Here, there is no contradiction in being Muslim and a proud Canadian, in being the descendent of a residential school survivor or prisoner of war and a proud Canadian, in being queer and a proud Canadian, etc. Any prospect of contradiction is ironed out by the relative freedoms ultimately afforded by 'our Canada' that sees each subject flourish. In this way, the exhibit as a whole both assumes and communicates a narrative of consensus, empathy and unanimity. The language of the curatorial statement suggests as much by observing that the portraits may 'remind you of your own experiences and challenges, or those of someone you know', and that while 'we are different', we are also 'the same', 'all connected'. To be sure, the individual stories featured here are interesting and worthy of representation. But the assumption of their relate-ability and the taken for granted consensus about 'what it means to work towards equality, inclusion and dignity for all Canadians' leaves little room for contradictory memories, ongoing experiences of violence or systemic discrimination or expressions of dissensus to emerge in conversation with these personal stories.

In 'Curatorial Practice and Learning from Difficult Knowledge', Roger Simon and I (2015) note the turn by contemporary museums to include personal stories as part of their exhibitions' miseen-scène in an effort to have publics see themselves as active participants in the museum. We argue, however, that there is a curatorial challenge inherent to this turn that requires more than simply providing a forum for various people to tell their stories. 'Storytelling', we suggest, 'has to be framed as an invitation to participate in establishing new relations between words and things as well as between objects and their meanings' (166), including possibilities for cultivating and expressing what French Philosopher Jacques Rancière calls 'dissensus'. To make room for dissensus is to recognize that there is 'no single regime of presentation and interpretation of the given imposing its obviousness on all [but] that every situation can be cracked open from the inside, reconfigured in a different regime of perception and signification' (Rancière 2009, 48-49). This challenge speaks to the limits of Our Canada, My Story as a narrative that takes for granted consensus and/or 'no contradiction', no dissensus, as its overarching framework. That is, while the stories featured in this exhibit are singularly compelling and explore a range of circumstances, their collection under the title and curatorial statement of Our Canada, My Story paints an unrealistically smooth picture of unity in the face of adversity/diversity. In doing so, the exhibit attempts to foreclose difficult knowledge by leaving out of the frame memories or stories that expose the ways in which Canada continues to discriminate against certain refugees, queers, Indigenous peoples and others - particularly those who do not strive for success through the pursuit of state-conferred rights but instead challenge the settler state's authority to bestow these rights precisely as a means of advocating for their own dignity and freedom or that of their communities'. 
Points of View: A National Human Rights Photography Exhibition was the CMHR's third featured exhibit for Canada 150. This exhibit was also developed in-house and sponsored by the GOC, and includes a collection of 70 images chosen from over 1000 submissions received in response to a public call for entries (CMHR 2017i). The collection is curated around five themes: freedom of expression, reconciliation, human rights and the environment, inclusion and diversity and youth. The photos are displayed throughout the multi-room gallery in groupings according to these themes, presented in uniform size and identically framed in crisp black with white matting. A 'Best Photograph' for each theme or category is highlighted by its own feature wall, accompanied by a text panel describing the image and a 'jury's statement' noting its merits. Protruding perpendicularly from these walls are haptic renderings (tactile models) of the winning photographs with push buttons indicated by Braille for English and French audio versions of the descriptions and jury's statements, an example of the Museum's 'inclusive design' for the visually impaired. Another wall features headshots and short biographies of the Points of View jury members, recognized as having 'wide-ranging backgrounds, in areas such as human rights, law, museum curation, photography, photojournalism and art' (CMHR 2017i). Interactive polling stations are distributed through the gallery prompting museumgoers with, 'What is your point of view? Use this station to vote for your favourite photograph!' In the centre of the gallery is a stylish seating area complete with two handsomely upholstered teak mid-century modern chairs and matching ottomans alongside a display of topical books and catalogues arranged on floating shelves against a wall painted with the exhibit's signature graphic) (Figure 6). Finally, an illuminated glass case stands at the exit of the gallery displaying a vintage camera and accessories propped around a Points of View t-shirt and stacks of the exhibit catalogue that are also for sale in the Museum Boutique.

Figure 6. Detail from Points of View: A National Human Rights Photography Exhibition (photo credit: author). 


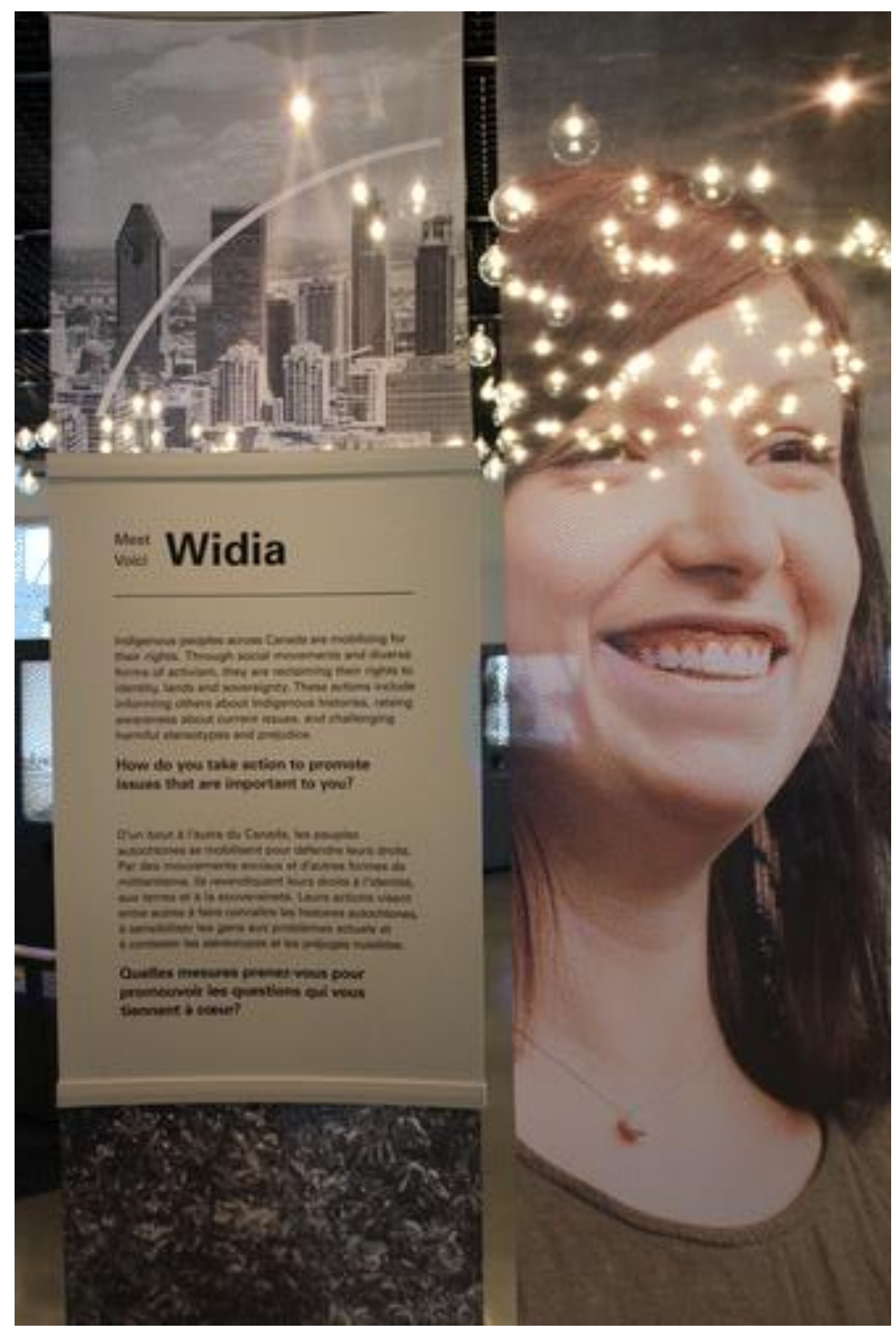

What is perhaps most striking about this exhibit is the way in which its attention to aesthetics and its performance of 'democratization' (i.e. through its emphasis on 'crowd-sourcing' nonprofessional or citizen photographers, having members of the public register their vote for a 'People's Choice Award', etc.) outstrips its critical engagement. The exhibit's patently benign curatorial statement anticipates as much:

Human rights stories are all around us. Sometimes it just takes a different point of view to bring them into focus. Points of View offers glimpses into how people perceive human rights around them - rights related to expression, inclusion and diversity, reconciliation and the environment. Some of these images may convey viewpoints similar to your own. Others may inspire you to think about an issue in a new way. We all have different points of view. What is yours? 
Despite the inclusion of some powerful images such as the now well-recognized photo by freelance journalist Ossie Michelin of an Elsipogtog First Nation protestor facing off with law enforcement over a shale gas exploration project, the depoliticized framing of the exhibit and its contents again demonstrates the Museum's investment in maintaining a non-disruptive or status quo approach to human rights. Ultimately, posturing an embracement of 'different' points of view without a curatorial framework that suggests in any way what the relationship of these images is to Canadian confederacy or the sesquicentennial anniversary limits the potential for this exhibit to foster engagement beyond a consideration of its aesthetic qualities.

\section{The late coming exhibit: a critical opening?}

The CMHR's fourth and final Canada 150 exhibit, Rights of Passage: Canada at 150, opened on 10 December 2017 after months of delays that in-house curators attribute to its ambitious scale and challenges associated with incorporating certain design elements featuring interactive digital technologies. ${ }^{5}$ Organized into five thematic 'zones' including Foundations and Dislocations (1867-1914), Transformations and Interventions (1915-1960), Towards the Charter (19601982), Human Rights in a Contemporary Canada (1982-present) and Defending Sovereignty

(past and present), this exhibit presents 33 different stories intended to 'explor[e] the key debates and issues that have been central to the evolution of the Canadian conversation on rights and freedoms, justice and equality'. These stories are told through various media including documentary videos, oral interviews, artefacts, archival radio and print materials, sound art and digital media interactives. What stands out about this exhibit is its deliberate attention to settlerIndigenous relations and the state's implication in human rights and Indigenous rights abuses, represented by panels addressing assimilationist policies such as the restrictive Indian Act and pass system for Indigenous peoples, residential schools and Indigenous resistance to land occupation (Figure 7). One panel, for instance, describes the Canadian government's repeated, forced relocations of the Ahiarmiut of Ennadai Lake, beginning in 1949, which resulted in the Inuit community's near annihilation due to starvation, disease and their dispossession of land and culture. The panel features a moving interview with elder David Serkoak, one of the community's few survivors, who shares his memories of being a child during the relocations and discusses more recent efforts by some members to return home. With this kind of attention, Rights of Passage encourages a genuine reckoning with the violations of colonialism and, as such, manages to shift away from the celebratory tone that permeates the other exhibits and programming of the Museum's Canada 150 showcase.

Figure 7. Detail from Rights of Passage: Canada at 150 (photo credit: author). 


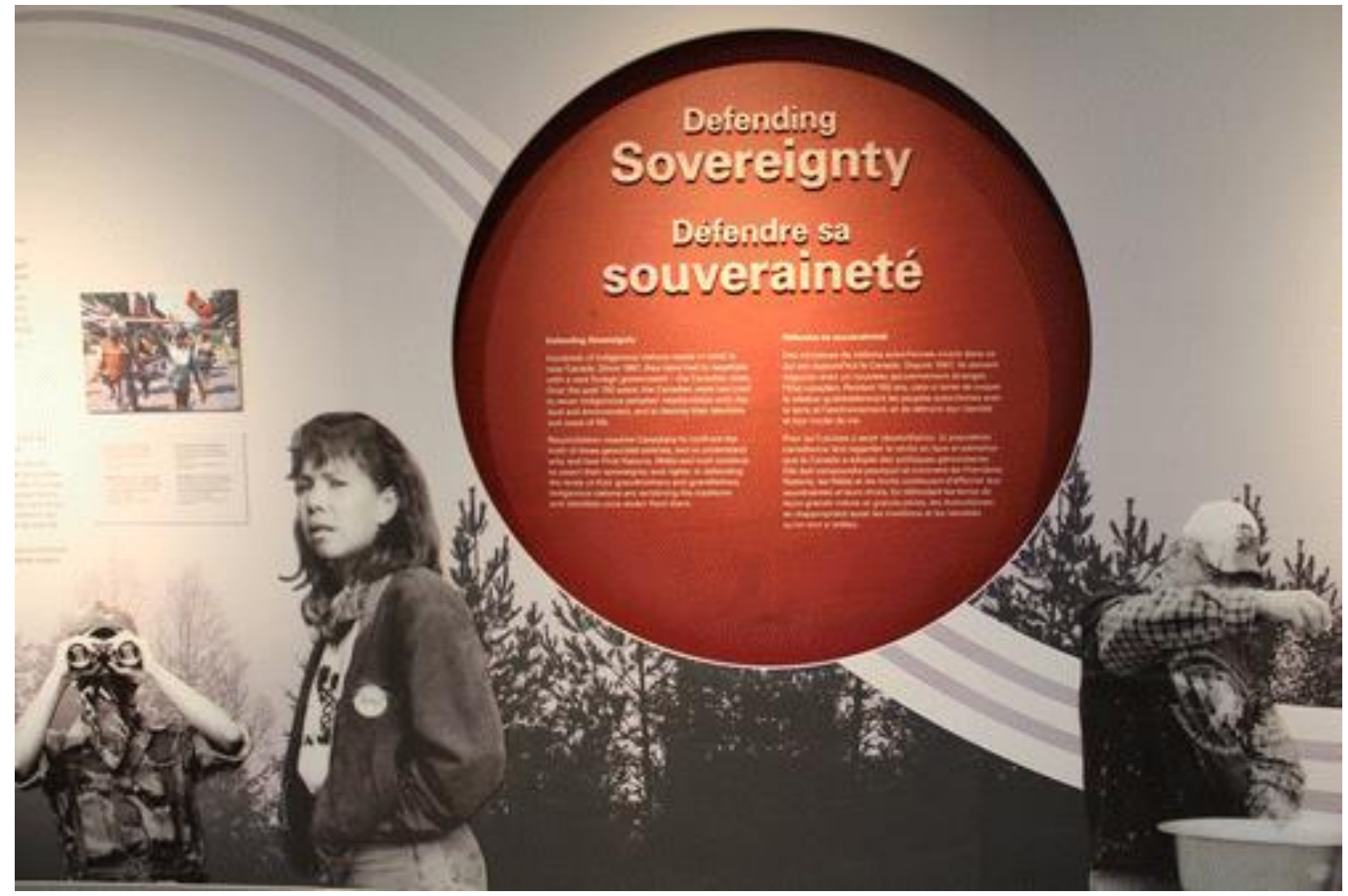

Rights of Passage takes a less reflexive turn, however, in its representation of transnational memory and politics. In a section called 'Canada and the World', it reverts back to selfcongratulatory mode in describing Canada's refugee settlement program, its role in democratic elections abroad and the Canadian Armed Forces' participation in a project to teach 'locals' in places like the former Yugoslavia and Afghanistan to recognize and avoid landmines. This section downplays Canada's involvement, past and present, in militarized conflicts abroad and at home, reinforcing the long-standing image of Canada as an 'innocent nation' (Razack 2017, 90), a benevolent peacekeeper on both the domestic and international scene. Inconsistencies such as this reflect a tension not just within this particular exhibit or even the Museum's Canada 150 showcase as a whole, but within the CMHR more broadly; that is, a tension between the efforts of curators trying to meaningfully address complex human rights issues (necessitating difficult/unsettling conversations) and pressures to provide museumgoers with 'a positive visitor experience' that can be counted on by tourism partners, corporate donors and government sponsors to generate public appeal and revenue. The late arrival of Rights of Passage, which, in my impression, is the one exhibit of the sesquicentennial showcase that potentially offers a critical opening by unsettling the status quo discourse surrounding the celebration of Canada 150 (albeit somewhat unevenly), is perhaps telling of the Museum's priorities in this respect. That the Museum also hosted a citizenship ceremony in one of its galleries on the day that Rights of Passage finally opened also drives home the reality that its institutional commitments lie with the settler state's conferral of rights and attendant framings of inclusion and belonging, even as it purports to respect divergent perspectives such as those on Indigenous sovereignty.

\section{Shoal Lake 40's MCHRV: resisting cozy nationalism, unsettling colonial memory}


The Shoal Lake 40 First Nation's Museum of Canadian Human Rights Violations (MCHRV) provides a powerful counterpoint to the CMHR and its Canada 150 showcase. Shoal Lake 40 First Nation (SL40) is an Anishinaabe community on the border of Manitoba and Ontario, about a two-and-a-half hour drive from Winnipeg. It has existed as an artificial island for almost a hundred years since the federal government unilaterally took their reserve land and lakebed and sold it for a token amount to the City of Winnipeg who proceeded to build a $155-\mathrm{km}$ aqueduct to transport water from the lake to supply the provincial capital. Completed in 1919, the aqueduct pushed the community off their traditional territory at the mouth of the Falcon River onto a narrow peninsula. The peninsula was then severed from the mainland when government engineers constructed a canal to divert Falcon River's tannin-stained water away from the aqueduct's intake pipe, setting the First Nation community afloat. Forced dislocation has hindered the community's capacity for economic sustainability and required its members to haul water, groceries and other provisions by a dilapidated ferry during the summer months and by foot or light vehicles over the frozen lake in winter. Residents have been killed falling through the ice. While Winnipeg enjoys some of the cleanest and safest drinking water in Canada, SL40 has been under a boil-water advisory for two decades, and remains cut off from other basic and emergency services (Failler and Sharma 2015; Perry 2016).

Despite a lack of broader political will to address the exploitative relationship between the state and the First Nation, SL40 has tirelessly advocated for change. Among its creative strategies include their launch of the MCHRV, an 'unofficial' museum run by volunteers. After crossing the lake by car and/or ferry like residents do, mainland tourists are brought along various stops in the community constituting the museum's 'exhibits': a community centre turned makeshift gallery space displaying an archive of the First Nation's long-standing struggle for justice including newspaper clippings, photographs, correspondence with public officials, letters to and from the CMHR and maps; a water container handling shed where rations for drinking and cooking are held; a provisional garbage dump where waste collects and decomposes because the community has no other means of disposal/removal; the dike that diverts tainted water away from the aqueduct's intake pipe, at the end of which a 'Private Property' sign demarks the land occupied by the City of Winnipeg, formerly the site of the community's village and burial grounds; and a temporary bridge over the canal near where the community has begun to build what they call 'Freedom Road'. The road, which will span $27 \mathrm{~km}$ to connect the community to the Trans-Canada highway, has been the main objective of SL40's ongoing lobbying efforts as well as a citizen led fundraising campaign trying to compensate for a lack of federal support. For the community the road is a matter of survival. When built, it will enable safe, all-season access in and out of SL40, as well as a means to develop local infrastructure including affordable water treatment and proper waste disposal.

In a press release announcing its launch, MCHRV curator Stewart Redsky explains that inviting visitors to view their entire community as a 'living museum' is a means of 'showing them all the injustices and the ways we're blocked from accessing the necessities of life' (Shoal Lake 2014). Strategically, SL40 launched its museum on the eve of the public opening of the CMHR. As part of its launch, community members set up a teepee outside the grandiose structure in Winnipeg, explaining to passers-by where the water came from that was used to fill the reflection pools in the CMHR's Garden of Contemplation envisioned by architect Antoine Predock to symbolise 'healing', and what the cost of this was to their community at the 'other end of the pipe' (Perry 2016, 96). In a letter published by the Globe and Mail, SL40 Chief Erwin Redsky and 
Pimicikamak Okimawin (Cross Lake) Chief Cathy Merrick called the CMHR a 'towering shrine to hypocrisy [...] a bitter reminder of what we do not have' (Redsky and Merrick 2014). Finally, public attention garnered by the MCHRV, including of the likes of celebrity-scientist David Suzuki, has nudged the CMHR into preliminary dialogue with SL40 and a promise to undertake oral histories with community members to be integrated into the museum's exhibits along with a commemorative plaque. ${ }^{6}$ But ultimately, SL40's priority is not to have better or more inclusive forms of recognition by the national museum. It is to restore the community's access to land and water that will allow it to meet its own basic needs, and to have a chance at economic development that being forced from the mainland has hitherto foreclosed.

As a visitor to Shoal Lake 40 and a participant in the MCHRV's tours on two occasions, my experience has been that the feeling cultivated here lies in stark contrast with the cozy nationalism that permeates the CMHR. Inviting visitors to witness their ravaged community, the 'emotional habitus' (Tyburczy 2016, 7) of the MCHRV's displays become invested with feelings of shock, despair, frustration and anger, along with astonishment at how the community has managed to persist given the devastating effects that settler colonial expansion has had on its peoples' cultural continuity and everyday survival. In this way, the MCHRV disrupts lovely knowledge and unsettles colonial frames of remembrance and recognition, cultivating affect as a means of resistance to the community's systematic exploitation and intentional 'forgetting' by the state. As such it expands conventional understandings of what a museum is and does, following through on the promise made by many contemporary museums to provide a forum for meaningful dialogue that can lead to social change. The MCHRV is also an example of decolonizing museum practice for the way that it prioritizes the repatriation of land and water for Indigenous peoples as a starting point for 'reconciliation'.

\section{Conclusion}

While it may not be realistic to expect that state-sponsored museums would take up the same kinds of critical and unsettling strategies that an 'unofficial', explicitly anti-colonial, Indigenous community-led museum like SL40 First Nation's MCHRV has, it is crucial that they be challenged to improve their representational practices and politics and live up to their mandates and stated objectives, particularly given their powerful role in creating narratives of national identity and contributing to public discourse and memory. I have argued in this paper that the CMHR's celebratory sesquicentennial showcase, with the partial exception of its latecoming Rights to Passage exhibit, largely fails to do so by reiterating colonial frames of remembrance and recognition as well as an uncritical 'multicultural nationalism' where Indigenous inclusion within the story of 'Canada's human rights journey' means being folded into a depoliticized framework of cultural diversity. And yet, it is apparent that individual curators at the CMHR have begun to envision ways of decolonizing the museum as evidenced by Rights of Passage and a recent paper on the topic published by two of its curatorial-research staff members (see Grafton and Peristerakis 2016). These curators deserve the support and prioritization of the institution to realize their visions. In turn, the Museum deserves a chance to live up to its aspiration (here again citing Murray) to divert from a 'paternalistic, colonial approach to Indigenous content that museums historically have at times been guilty of' (CMHR 2012). The public, too, deserves this chance if we are to expand our understanding of how museums might contribute to decolonization as part of the process of reconciliation in Canada. 


\section{Disclosure statement}

No potential conflict of interest was reported by the author.

\section{Funding}

This research is supported by the Social Sciences and Humanities Research Council of Canada with funding through the Canada Research Chair and Partnership Development Grant programs.

\section{Notes}

1. On this point, see Amber Dean's discussion wherein she describes an example of the CMHR's inability to respond to an immediate crisis on its doorsteps: as Winnipegers gathered at the Forks to protest and mourn the violent death of Tina Fontaine, a young woman from nearby Sagkeeng First Nation whose body was recovered just upriver from and in view of the CMHR, the Museum remained silent on the issue, using its social media feeds to instead promote its gift shop and new postage stamp (Dean 2015).

2. I base this observation in part on the fact that despite having an active membership with the CMHR and following its communications and promotions for research purposes, I was unaware of either dialogue event until after they occurred. To date, the Museum has also not made any proceedings related to these events available, thus I am not able to evaluate or comment on them any further here.

3. For further discussion on the significance of this location, including the highly publicized findings of an archaeological dig undertaken prior to the Museum's construction, see Failler (2015) and Wong (2014). On the significance of this location with respect to the CMHR being part of a civic project to revitalize downtown Winnipeg and the Forks area, see Wodtke (2015) and Dean and Failler (forthcoming).

4. The Haudenosaunee are a confederacy of Indigenous nations including the founding nations of the Seneca, Cayuga, Tuscarora, Onondaga, Oneida and Mohawk (2017).

5. This explanation was offered by curators of the exhibit at a members' preview held on 7 December 2017.

6. Discussed by Karine Duhamel in her keynote presentation 'Kanata/Canada: Re-storying "Canada 150" at the Canadian Museum for Human Rights' for Re-thinking the Museum Through Collaboration and Community-Based Curatorial Practices at NSCAD University, Halifax, Nova Scotia, 24-26 April 2017. 


\section{References}

Belcourt, Christi. 2017. “Canada, I Can Cite for You 150.” In Surviving Canada: Indigenous Peoples Celebrate 150 Years of Betrayal, edited by Kiera L. Ladner and MyraTait, 129_ 130. Winnipeg: Arbeiter Ring Publishing.

Bociurkiw, Marusya. 2011. Feeling Canadian: Television, Nationalism, and Affect. Waterloo: Wilfrid Laurier University Press.

Busby, Karen, Adam Muller, and Andrew Woolford. 2015. The Idea of a Human Rights Museum. Winnipeg: University of Manitoba Press.

CAPP (Canadian Association of Petroleum Producers). 2017. "About Us.” Canadian Association of Petroleum Producers. Accessed October 25. http://www.capp.ca/about-us.

Clearsky, Grand Chief Murray. 2013. "Canada Sanitizing First Nations Genocide." Censored News, August 1. http://bsnorrell.blogspot.ca/2013/08/chief-clearsky-canada-sanitizing-first.html.

CMH (Canadian Museum of History). 2016. "1867-Rebellion and Confederation." Canadian Museum of History. Accessed October 25, 2017. http://www.historymuseum.ca/1867-rebellionand-confederation/.

CMHR (Canadian Museum for Human Rights). 2011. "Speech Delivered by President and CEO Stuart Murray to University of Manitoba 'Thinking about Ideas Museums' Speaker Series." September 9. https://humanrights.ca/about-museum/news/speech-delivered-president-and-ceostuart-murray-university-manitoba-thinking.

CMHR (Canadian Museum for Human Rights). 2012. "Speech Delivered by President and CEO Stuart Murray to L'Union Nationale Métisse Saint-Joseph Du Manitoba.” July 13. https://humanrights.ca/about-museum/news/speech-delivered-president-and-ceo-stuartmurray-lunion-nationale-metisse-saint.

CMHR (Canadian Museum for Human Rights). 2014. "CMHR Announces Admission Prices and Hours." Canadian Museum for Human Rights, June 6. https://humanrights.ca/aboutmuseum/news/cmhr-announces-admission-prices-and-hours.

CMHR (Canadian Museum for Human Rights). 2014-15. "The Conversation Begins: 2014-15 Annual Report." Canadian Museum for Human

Rights. https://humanrights.ca/sites/default/files/media/2014-2015_annual_report_en.pdf.

CMHR (Canadian Museum for Human Rights). 2016a. "Asian Heritage Month: An Interview with Pardeep Singh Nagra." Canadian Museum for Human Rights, May

26. https://humanrights.ca/blog/asian-history-month-interview-pardeep-singh-nagra. 
CMHR (Canadian Museum for Human Rights). 2016b. "Seven Fascinating Artifacts You Can See at the 1867: Rebellion and Confederation Exhibit." Canadian Museum for Human Rights, December 15. https://humanrights.ca/blog/seven-fascinating-artifacts-you-can-see-1867rebellion-confederation-exhibition.

CMHR (Canadian Museum for Human Rights). 2017a. "1867: Rebellion and Confederation." Canadian Museum for Human Rights. Accessed October 25. https://humanrights.ca/exhibit/1867-rebellion-confederation.

CMHR (Canadian Museum for Human Rights). 2017b. "About the Museum." Canadian Museum for Human Rights. Accessed October 25. https://humanrights.ca/about.

CMHR (Canadian Museum for Human Rights). 2017c. "At the Boutique." Canadian Museum for Human Rights. Accessed October 25. https://humanrights.ca/exhibitions/1867-rebellionconfederation/boutique.

CMHR (Canadian Museum for Human Rights). 2017d. "Canada Day.” Canadian Museum for Human Rights. Accessed November 25. https://humanrights.ca/event/canada-day-0.

CMHR (Canadian Museum for Human Rights). 2017e. "Contributing to Reconciliation." Canadian Museum for Human Rights. Accessed November

19. https://humanrights.ca/about/mandate-and-museum-experience/contributing-reconciliation.

CMHR (Canadian Museum for Human Rights). 2017f. "Countdown to Canada's 150th." Canadian Museum for Human Rights. Accessed October 25. https://humanrights.ca/event/countdown-canadas-150th.

CMHR (Canadian Museum for Human Rights). 2017g. "Museum Lights Up Red for Canada 150." Canadian Museum for Human Rights, June 28. https://humanrights.ca/aboutmuseum/news/museum-lights-red-canada-150.

CMHR (Canadian Museum for Human Rights). 2017h. "Our Canada, My Story.” Canadian Museum for Human Rights. Accessed October 25. https://humanrights.ca/exhibit/our-canada-mystory/about-the-exhibit.

CMHR (Canadian Museum for Human Rights). 2017i. "Points of View: A National Human Rights Photography Exhibition." Canadian Museum for Human Rights. Accessed October 25. https://humanrights.ca/exhibit/points-view-national-human-rights-photography-exhibition.

CMHR (Canadian Museum for Human Rights). 2017j. "Programs and Activities, 1867: Rebellion and Confederation." Canadian Museum for Human Rights. Accessed October 25. https://humanrights.ca/exhibitions/1867-rebellion-confederation/programs-and-activities.

CMHR (Canadian Museum for Human Rights). 2017k. "The Rebellion in Rebellion and Confederation." Canadian Museum for Human Rights. Accessed January 24. https://humanrights.ca/blog/rebellion-rebellion-confederation. 
CMHR (Canadian Museum for Human Rights). 20171. "Rights of Passage: Canada at 150." Canadian Museum for Human Rights. Accessed December

12. https://humanrights.ca/explore/exhibitions/rights-passage-canada-150/about-exhibit.

Coulthard, Glen S. 2014. Red Skin White Masks: Rejection the Colonial Politics of

Recognition. Minneapolis: University of Minnesota Press. DOI:

10.5749/minnesota/9780816679645.001.0001.

Dean, Amber. 2015. "The CMHR and the Ongoing Crisis of Murdered or Missing Indigenous Women: Do Museums Have a Responsibility to Care?" Review of Education, Pedagogy and Cultural Studies 37 (2/3): 147-165. DOI: 10.1080/10714413.2015.1028834.

Dean, Amber, and Angela Failler. Forthcoming. "An Amazing Gift? Memory Entrepreneurship, Settler Colonialism and the Canadian Museum for Human Rights.” TBA.

Dhamoon, Rita Kaur. 2016. "Re-presenting Genocide: The Canadian Museum of Human Rights and Settler Colonial Power." Journal of Race, Ethnicity and Politics 1, no. 1 (March): 5-30. DOI: $10.1017 /$ rep.2015.4.

Di Gregorio, Michael, and Jessica L. Merolli. 2016. "Introduction: Affective Citizenship and the Politics of Identity, Control, Resistance.” Citizenship Studies 20 (8): 933-942. DOI:

10.1080/13621025.2016.1229193.

Failler, A. 2015. "Hope without Consolation: Prospects for Critical Learning at the Canadian Museum for Human Rights." Review of Education, Pedagogy and Cultural Studies 37 (2/3): 227-250. DOI: 10.1080/10714413.2015.1028843.

Failler, Angela, Peter Ives, and Heather Milne, eds. 2015. "Introduction: Caring for Difficult Knowledge - Prospects for the Canadian Museum for Human Rights." Review of Education, Pedagogy and Cultural Studies 37 (2/3): 100-105.

Failler, Angela, and Karen Sharma. 2015. "Shoal Lake 40's Living Museum: A Photo Essay." Cultural Studies Research Group, University of Winnipeg, July 23. https://wwwuwinnipeg-ca.uwinnipeg.idm.oclc.org/csrg/projects/shoal-lake-photo-essay\%20.html.

Failler, Angela, and Roger I. Simon. 2015. "Curatorial Practice and Learning from Difficult Knowledge." In The Idea of a Human Rights Museum, edited by Karen Busby, AdamMueller, and Andrew Woolford, 165-179. Winnipeg: University of Manitoba Press.

The Forks. n.d. "History." The Forks. http://www.theforks.com/about/history.

Gordon-Walker, Caitlin. 2016. Exhibiting Nation: Multicultural Nationalism (and Its Limits) in Canada's Museums. Vancouver: University of British Columbia Press.

Grafton, Emily, and Julia Peristerakis. 2016. "Decolonizing Museological Practices at the Canadian Museum for Human Rights." In Indigenous Notions of Ownership and Libraries, 
Archives and Museums, edited by Camille Callison, Loriene Roy, and Gretchen Alice LeCheminant, 229-243. Berlin/Munich: De Gruyter Saur.

Haudenosaunee Confederacy. 2017. “The League of Nations.” Haudenosaunee Confederacy. Accessed October 25. http://www.haudenosauneeconfederacy.com/leagueofnations.html.

Hankivsky, Olena, and Rita Dhamoon. 2013. "Which Genocide Matters the Most? An Intersectionality Analysis of the Canadian Museum for Human Rights." Canadian Journal of Political Science 46 (4): 899-920. DOI: 10.1017/S000842391300111X.

Henderson, James (Sa'ke'j) Youngblood. 2017. "O Canada: 'A Country Cannot Be Built on a Living Lie'." In Surviving Canada: Indigenous Peoples Celebrate 150 Years of Betrayal, edited by Kiera L. Ladner and Myra Tait, 277-289. Winnipeg: Arbeiter Ring Publishing.

Henderson, Jennifer, and Pauline Wakeham, eds. 2013. Reconciling Canada: Critical Perspectives on the Culture of Redress. Toronto: University of Toronto Press.

Idle No More. 2017. "Unsettling Canada 150: A Call to Action." Idle No More, May 5. http://www.idlenomore.ca/unsettling_150_a_call_to_action.

Kassam, Ashifa. 2017. "Canada Celebrates 150 but Indigenous Groups Say History is Being 'Skated Over'." The Guardian, June

27. https://www.theguardian.com/world/2017/jun/27/canada-150th-anniversary-celebrationindigenous-groups.

Ladner, Kiera L., and Myra Tait, eds. 2017. Surviving Canada: Indigenous Peoples Celebrate 150 Years of Betrayal. Winnipeg: Arbeiter Ring Publishing.

Lehrer, Erica. 2015. "Thinking Through the Canadian Museum for Human Rights." American Quarterly 67, no. 4 (December): 1195-1216. DOI: 10.1353/aq.2015.0076.

Logan, Tricia. 2014. "National Memory and Museums: Remembering Settler Colonial Genocide of Indigenous Peoples in Canada." In Remembering Genocide, edited by NigelEltringham and Pam MacLean, 112-130. New York: Routledge.

Lonetree, Amy. 2012. Decolonizing Museums: Representing Native America in National and Tribal Museums. Chapel Hill: The University of North Carolina Press.

Mctavish, Lianne, Susan Ashley, Heather Igloliorte, Kirsty Robertson, and Andrea Terry. 2017. "Critical Museum Theory/Museum Studies in Canada: A Conversation." Acadiensis: Journal of the History of the Atlantic Region 46 (2): 223-241.

Moses, A. Dirk. 2012. "The Canadian Museum for Human Rights: The "Uniqueness of the Holocaust' and the Question of Genocide.” Journal of Genocide Research 14 (2): 215-238. DOI: 10.1080/14623528.2012.677762. 
Murray, David. 2014. "The (Not So) Straight Story: Queering Migration Narratives of Sexual Orientation and Gendered Identity Refugee Claimants.” Sexualities 17 (4): 451-471. DOI: $10.1177 / 1363460714524767$.

Perry, Adele. 2016. Aqueduct: Colonialism, Resources, and the Histories We Remember. Winnipeg: Arbiter Ring Publishing.

Phillips, Ruth B. 2006. "Show Times: De-Celebrating the Canadian Nation, De-Colonising the Canadian Museum, 1967-92." In Rethinking Settler Colonialism: History and Memory in Australia, Canada, Aotearoa New Zealand and South Africa, edited by Annie E. Coombes, 121139. Manchester, NH: Manchester University Press.

Phillips, Ruth B. 2011. Museum Pieces: Toward the Indigenization of Canadian Museums. Montréal and Kingston: McGill-Queens University Press.

Pitt, Alice, and Deborah Britzman. 2003. "Speculations on Qualities of Difficult Knowledge in Teaching and Learning: An Experiment in Psychoanalytic Research." International Journal of Qualitative Studies in Education 16 (6): 755-776. DOI: 10.1080/09518390310001632135.

Rancière, Jacques. 2009. The Emancipated Spectator. Translated by Gregory Elliot. Brooklyn, NY: Verso.

Razack, Sherene. 2017. “The Impact of Systemic Racism on Canada's Pre-Bombing Threat Assessment and Post-Bombing Response to the Air India Bombings." In Remembering Air India: The Art of Public Mourning, edited by Chandrima Chakraborty, Amber Dean, and Angela Failler, 85-117. Edmonton: University of Alberta Press.

Redsky, Erwin, and Cathy Merrick. 2014. "For Our First Nations, New Museum a Monument to Hypocrisy." Globe and Mail, September 25. https://www.theglobeandmail.com/opinion/for-ourfirst-nations-new-museum-a-monument-to-hypocrisy/article20784499/.

Ross, Max. 2004. "Interpreting the New Museology.” Museum and Society 2, no. 2 (July): 84103.

Scott, Cam. 2015. "CMHR: The Unbearable Lightness of Inclusion.” Canadian Dimension49, no. 3 (May/June): 84-103. https://canadiandimension.com/articles/view/cmhr-the-unbearablelightness-of-inclusion.

Shoal Lake 40 First Nation. 2014. "Press Release: Shoal Lake 40 Launches the Museum of Canadian Human Rights Violations.” Shoal Lake 40 First Nation, September 15, 2015. http://www.s140.ca/docs/CMHRVPressRelease.pdf.

Stam, Deirdre C. 1993. “The Informed Muse: The Implications of 'The New Museology' for Museum Practice.” Museum Management and Curatorship 12 (3): 267-283. [Taylor \& Francis Online]. 
Sumanac-Johnson, Deana. 2017. "Telling Their Stories or Opting out: Indigenous Artists on Canada 150." CBC News, February 7. http://www.cbc.ca/news/entertainment/indigenous-artistscanada-150-1.3968556.

TRC (Truth and Reconciliation Commission of Canada). 2015a. Calls to Action. Winnipeg: Library and Archives Canada Cataloguing in

Publication. http://www.trc.ca/websites/trcinstitution/File/2015/Findings/Calls_to_Action_Englis h2.pdf.

TRC (Truth and Reconciliation Commission of Canada). 2015b. Honouring the Truth, Reconciling for the Future: Summary of the Final Report of the Truth and Reconciliation Commission of Canada. Winnipeg: Library and Archives Canada Cataloguing in Publication. http://www.trc.ca/websites/trcinstitution/File/2015/Honouring_the_Truth_Reconcili ng_for_the_Future_July_23_2015.pdf.

Tuck, Eve, and K. Wayne Yang. 2012. "Decolonization is Not a Metaphor." Decolonization: Indigeneity, Education \& Society 1 (1): 1-40.

Tyburczy, Jennifer. 2016. Sex Museums: The Politics and Performance of Display. Chicago and London: The University of Chicago Press.

Unsettling Canada 150. n.d. http://unsettling150.ca/.

Vergo, Peter. 1989. The New Museology. London: Reaktion Books.

West, Richard W., ed. 2001. The Changing Presentation of the American Indian: Museums and Native Cultures. Seattle: University of Washington Press.

Wodtke, Larissa. 2015. "A Lovely Building for Difficult Knowledge: The Architecture of the Canadian Museum for Human Rights." Review of Education, Pedagogy and Cultural Studies 37 (2/3): 207-226.

Winnipeg Art Gallery. 2017. Insurgence/Resurgence [Exhibition] Curated by Jaimie Isaac and Julie Nagam. September 22, 2017-April 22, 2018. http://wag.ca/art/exhibitions/currentexhibitions/display,exhibition/206/insurgence-resurgence.

Wolf, Patrick. 2006. "Settler Colonialism and the Elimination of the Native." Journal of Genocide Research 8 (4): 387-409. DOI: 10.1080/14623520601056240.

Wong, Kimlee. 2014. "Human Rights Hypocrisy: The Canadian Museum for Human Rights.” Global Research, September 12. https://www.globalresearch.ca/human-rightshypocrisy-the-canadian-museum-for-human-rights/5401336. 